\title{
PENINGKATKAN VISUAL SPASIAL ANAK MELALUI KEGIATAN BERMAIN MAZE PADA ANAK DI RA SABARIYAH KELURAHAN HARJOSARI II KECAMATAN MEDAN AMPLAS
}

\author{
Widya Masitah dan Sri Wahyuni \\ Dosen Fakultas Agama Islam Universitas Muhammadiyah Sumatera Utara \\ (Email: widya.masitah@yahoo.co.id)
}

\begin{abstract}
Abstrak
Penelitian ini merupakan penelitian tindakan kelas yang dilakukan di kelas peneliti yaitu kelompok B RA Sabariyah Kelurahan Harjosari II dengan jumlah anak sebanyak 17 anak dengan 10 anak laki-laki dan 7 anak Perempuan.Teknik analisis data yang digunakan adalah tes, observasi, wawancara dan dokumentasi. Penelitian dilakukan melalui 3 siklus dengan empat tahapan yaitu perencanaan, pelaksanaan, pengamatan dan refleksi. Hasil penelitian menunjukkan bahwa visual spasial anak dapat ditingkatkan dengan menggunakan media bermain maze pada RA Sabariyah Kelurahan Harjosari II Kecamatan Medan Amplas Tahuan ajaran 2015/2017, hal tersebut dapat dilihat dari hasil penelitian pada setiap siklus; prasiklus visual spasial anak sangat rendah yaitu hasil persentase rata-rata sebesar $26,5 \%$, pada siklus 1 hasil persentase rata-rata sebesar $41 \%$, pada siklus 2 hasil persentase rata-rata sebesar $57,5 \%$ dan pada siklus 3 rata-rata sebesar $85 \%$.
\end{abstract}

Keywords : : Visual spasial, bermain maze

Korespondensi : FAI Universitas Muhammadiyah Sumatera Utara Jalan Kapten Mukhtar Basri No. 03 Medan

\section{A. Pendahuluan}

\section{Latar Belakang Masalah}

Pendidikan adalah usaha sadar dan terencana untuk mewujudkan suasana belajar dan proses pembelajaran agar peserta didik secara aktif mengembangkan potensi dirinya untuk memiliki kekuatan spiritual keagamaan, pengendalian diri, kepribadian, kemampuan, akhlak mulia, serta keterampilan yang diperlukan dirinya, masyarakat, bangsa dan negara. Pendidikan sebagai suatu proses, baik berupa pemindahan maupun penyempurnaan akan melibatkan dan mengikutsertakan bermacam-macam komponen dalam rangka mencapai tujuan yang diharapkan.

Pendidikan berlangsung seumur hidup sejak anak lahir sampai akhir hayat. Pentingnya pendidikan diberikan pada anak usia dini terdapat di dalam Undang-undang Sisdiknas Nomor 20 Tahun 2003 Peraturan Pemerintah tentang Pendidikan Anak Usia Dini pasal 1 ayat 1 , dinyatakan bahwa: 
Pada masa usia dini, selain bermain sebagai bentuk kehidupan dalam kecakapan memperoleh keterampilannya, anak-anak juga sudah dapat menerima berbagai pengetahuan dalam pembelajaran secara akademis untuk persiapan mereka memasuki pendidikan dasar selanjutnya. Pada masa ini, anak-anak mengalami masa peka atau masa sensitif dalam menerima berbagai upaya pengembangan seluruh potensi yang dimilikinya. Masa peka merupakan masa terjadinya pematangan fungsi-fungsi fisik dan psikis yang siap merespon rangsangan yang diberikan oleh lingkungan. ${ }^{1}$

Berdasarkan pengalaman peneliti bahwa kemampuan anak masih rendah khususnya dalam visual spasialnya hal ini dapat dilihat dari kurangnya kemampuan anak dalam menyelesaikan tugas menggambar, kurangnya kreativitas anak, kemampuan anak dalam membuat coretan masih rendah, anak belum mampu membuat prakarya dengan baik, dengan adanya masalah tersebut maka peneliti menggunakan kegiatan bermain maze dalam meningkatkan

\footnotetext{
${ }^{1}$ Dikdasmen, Pedoman Pengembangan Program Pembelajaran di Taman Kanakkanak, (Jakarta: Kemendiknas, 2010), h. 28
}

kemampuan visual spasial anak. Permainan maze adalah permainan edukatif dengan jalan sempit yang berliku dan berbelok dan kadang kala merupakan jalan buntu ataupun jalan yang mempunyai halangan, dapat juga dikatakan permainan mencari jalan keluar sehingga anak bisa menemukan jalan keluarnya. Maze adalah sesuatu yang sangat rumit dan berbelit-belit. ${ }^{2}$

Berdasarkan permasalahan tersebut, peneliti ingin meneliti tentang visual spasial anak dengan menggunakan kegiatan bermain maze dalam bentuk penelitian Tindakan Kelas dengan menganalisisnya dalam karya ilmiah dengan judul penelitian "Peningkatan Visual Spasial Anak Melalui Kegiatan Bermain Maze Pada Anak RA Sabariyah Kelurahan Harjosari II Kecamatan Medan Amplas". Alasan penggunaan permainan maze karena kemampuan anak menunjukkan dan menguasasi gerakan-gerakan otot indah dalam bentuk koordinasi, ketangkasan dan kecekatan dalam menggunakan tangan dan jari jemari. Kegiatan ini merujuk pada Kurikulum RA Tahun 2011 dalam bidang pengembangan motorik dengan indikator memperkenalkan dan

\footnotetext{
${ }^{2}$ Tadkiroatun Musfiroh, Cerdas Melalui Bermain, (Jakarta: Grasindo, 2008), h. 298.
} 
melatih gerakan tubuh dan koordinasi, serta meningkatkan keterampilan tubuh dan cara hidup sehat sehingga dapat menunjang pertumbuhan jasmani yang kuat sehat dan terampil. ${ }^{3}$

\section{Identifikasi Masalah}

Berdasarkan permasalahan di atas maka dapat diidentifikasikan masalah sebagai berikut:

a. Kemampuan anak dalam menggambar masih rendah.

b. Kemampuan anak menyesuaikan warna belum tepat.

c. Kemampuan anak meletakkan benda-benda belum efektif.

\section{Perumusan Masalah}

$$
\text { Berdasarkan berbagai }
$$

identifikasi masalah di atas, dan agar proses pembelajaran berjalan efektif dan terarah, maka penulis merumuskan permasalahannya yaitu apakah visual spasial anak meningkat melalui kegiatan bermain maze pada anak di RA Sabariyah Kelurahan Harjosari II Kecamatan Medan Amplas?

\section{Cara Memecahkan Masalah}

Cara memecahkan masalah dalam PTK ini adalah bermain dalam

${ }^{3}$ Depdiknas, Kurikulum 2003 Standar Komputer TK dan RA (Jakarta:Direktorat Jendral Pendidikan Dasar dan Menengah,2007), h.11 meningkatkan visual spasial anak dengan kegiatan bermain maze.

\section{Hipotesis Tindakan}

Rumusan hipotesis tindakan dalam PTK ini adalah: "melalui kegiatan bermain maze pada anak di RA Sabariyah Kelurahan Harjosari II Kecamatan Medan Amplas dapat meningkatkan visual spasial anak".

\section{Tujuan Penelitian}

Adapun tujuan dilakukannya penelitian tindakan kelas adalah "untuk mengetahui peningkatan visual spasial anak melalui kegiatan bermain maze pada anak di RA Sabariyah Kelurahan Harjosari II Kecamatan Medan Amplas agar anak dapat pengembangan memiliki kemampuan dalam menggambar, kemampuan anak menyesuaikan warna dan kemampuan anak meletakkan benda-benda.

\section{Manfaat Penelitian}

Manfaat dalam penelitian ini terbagi dua diantaranya:

1. Manfaat Teoretis

Sebagai bahan pengembangan ilmu pengetahuan dalam rangka penyelenggara pendidikan serta pentingnya proses belajar mengajar yang dilaksanakan dengan perencanaan matang, 


\begin{abstract}
kelengkapan alat dan media pembelajaran yang digunakan, sarana dan prasarana belajar dan pemenuhan kebutuhan penyelenggaraan proses belajar mengajar.
\end{abstract}

2. Manfaat Praktis

a. Bagi Anak

1) Sebagai motivasi bagi anak untuk melakukan gerakan visual spasial anak dengan bermain.

2) Meningkatkan kemampuan motorik anak dengan kegiatan bermain maze dan menambah kreativitas anak.

b. Bagi Guru

1) Sebagai bahan masukan dalam penggunaan gaya belajar bagi anak usia dini

2) Menambah wawasan bagi guru dalam meningkatkan kemampuan visual spasial anak.

c. Bagi Sekolah
1) Hasil penelitian diharapkan dapat

menumbuhkan suasana belajar yang efektif, inovatif, kreatif dan menyenangkan.

2) Pengaplikasian teori yang telah diperoleh sehingga dimungkinkan semangat kerja warga sekolah semakin tinggi dan efisien.

d. Bagi Peneliti

1) Menjadi bahan dan landasan dalam mengembangkan gaya belajar yang bervariasi yang akan meningkatkan visual spasial anak.

2) Sebagai referensi bagi peneliti dalam mengembangkan kemampuan visual spasial anak dan sebagai acuan dalam pembelajaran yang akan datang.

\section{Manfaat akademis}

Sebagai bahan sumbangan bagi pengembangan Ilmu pengetahuan dengan permasalahan perkembangan visual spasial anak melalui kegiatan bermain maze. 


\section{B. Landasan Teoretis}

\section{Pengertian Visual Spasial Anak}

\begin{tabular}{|c|c|c|}
\hline \multicolumn{2}{|c|}{ Kemampuan } & menurut \\
\hline Poerwadarminta & adalah & "mampu \\
\hline artinya & (bisa, & sanggu \\
\hline elakukan & & sedar \\
\hline mampuan & & 20 \\
\hline
\end{tabular}

Kemampuan menurut Slameto adalah "kecakapan yang terdiri dari tiga jenis yaitu kecakapan untuk menghadapi dan menyesuaikan kedalam situasi yang baru dengan cepat dan efektif, mengetahui / menggunakan konsep-konsep yang abstrak secara efektif, mengetahui relasi dan mempelajarinya dengan cepat. ${ }^{5}$

Berdasarkan pengertian di atas, maka dapat disimpulkan bahwa kemampuan visual spasial adalah kemampuan untuk membentuk suatu gambaran tentang tata ruang didalam pikiran. Anak anak dengan kemampuan visual-spasial yang tinggi cenderung berpikir secara visual. Mereka kaya khayalan internal (internal imagery) sehingga cenderung imajinatif dan kreatif.

\footnotetext{
4 W.J.S Poerwadarmita, Kamus Lengkap Bahasa Indonesia (Jakarta: Indeks, 2007), h.742

${ }^{5}$ Slameto, Belajar dan Faktor-faktor yang Mempengaruhinya (Jakarta: Rineka Cipta,2010), h. 56
}

2. Tahap-tahap Perkembangan Kemampuan Visual Spasial

Menurut Sujiono menguraikan bagaimana mengembangkan cara kemampuan visual spasial pada anak sebagai berikut:

a. Mencoret-coret, untuk mampu menggambar, anak memulainya dengan mencoret-coret terlebih dahulu. Mencoret biasanya dimulai sejak anak berusia sekitar 18 bulan, tapi pada dasarnya kegiatan mecoret merupakan sarana anak mengekspresikan diri. Meskipun coretannya belum tentu langsung terlihat isi pikirannya. Selain itu kegiatan ini dapat melatih koordinasi tangan-mata anak.

b. Menggambar dan melukis, kegiatan menggambar dapat dilakukan dimana saja dan kapan saja dengan biaya yang relatif murah. Sediakan alat-alat yang diperlukan, seperti kertas, pensil warna, dan krayon. Biarkan anak melukis atau menggambar apa yang ia inginkan dan sesuai imajinasi dan kreativitasnya. Karena menggambar dan melukis adalah ajang bagi anak untuk mengekspresikan diri. 
Kegiatan membuat prakarya atau kerajinan tangan menuntut kemampuan anak memanipulasi bahan. Kreativitas dan imajinasi anakpun terlatih karenanya. Selain itu kerajinan tangan dapat membangun kepercayaan diri anak.

d. Mengunjungi berbagai tempat, dapat memperkaya pengalaman visual spasial anak. Seperti mengajaknya ke museum, kebun binatang, menempuh perjalanan alam lainnya.

e. Melakukan permainan konstrutif dan kreatif, sejumlah permainan seperti membangun konstruksi dengan mengunakan balok, puzzle, permainan rumah-rumahan, atau peralatan video, film, peta, atau gambar

f. Mengatur dan merancang, kejedian anak untuk mengatur dan merancang juga dapat diasah dengan mengajaknya dalam kegiatan mengatur ruang dirumah. Seperti ikut menata kamar tidurnya. Kegiatan ini dapat meningkatkan kepercayaan diri anak bahwa ia mampu memutuskan sesuatu. g. Pengenalan informasi visual, informasi visual mengacu pada pesan pengetahuan yang dituangkan dalam bentuk nonverbal. Pesan pengetahuan disampaikan dalam bentuk grafik/ diagram dan denah. ${ }^{6}$

\section{Indikator Kemampuan Visual Spasial Anak Usia Dini}

Anak yang mengalami Perkembangan kemampuan visual spasial yang sangat menonjol kadang mengalami kesulitan mengidentifikasi simbol bahasa tertulis. Kemampuan visual spasial memiliki indikator sebagai berikut:

a. Individu yang cerdas secara visual (lebih) mudah membaca peta, gambar, grafik, dan diagram.

b. Individu yang cerdas secara visual menonjol dalam seni lukis dan karya.

c. Individu yang cerdas secara visual mampu memberikan gambaran visual yang jelas ketika memikirkan sesuatu.

d. Individu yang cerdas secara visual mampu menggambar sosok orang atau benda menyerupai aslinya.

\footnotetext{
${ }^{6}$ Ahmad Susanto, Perkembangan Anak Usia Dini Pengantar dalam erbagai Aspeknya, (Jakarta: Kencana, 2011), h. 61
} 
e. Individu yang cerdas secara visual menyukai film, video, slide, gambar atau foto.

f. Individu yang cerdas secara visual menikmati permainan yang membutuhkan ketajaman, seperti zigzaw, maze.

g. Anak memiliki kepekaan terhadap warna, cepat mengenali warna, dan mampu memadukan warna dengan lebih baik daripada anak-anak sebayanya.

h. Anak suka menjelajahi lokasi disekitarnya dan memperhatikan tata letak benda-benda yang ada disekitarnya. Serta cepat menghafal letak benda-benda.

i. Anak menyukai balok tau benda lain untuk membuat suatu bangun benda, seperti mobil, rumah, pesawat, ataupun yang diinginkan anak. Mengacu dari berbagai uraian diatas, dapat disimpulkan bahwa kemampuan visual spasial anak yang diperoleh adalah dapat meningkatkan minat belajar anak, meningkatkan daya ingat anak, mampu memecahkan masalah, dan lebih tertarik dalam pembelajaran. ${ }^{7}$

\section{Pengertian Bermain Maze}

Permainan maze adalah permainan edukatif dengan jalan sempit yang berliku dan berbelok dan kadang kala merupakan jalan buntu ataupun jalan yang mempunyai halangan, dapat juga dikatakan permainan mencari jalan keluar sehingga anak bisa menemukan jalan keluarnya. Maze adalah sesuatu yang sangat rumit dan berbelit-belit. Dalam kehidupan sehari-hari, Maze dan labirin (labyrinth) seringkali dianggap sama, yaitu sebagai jalan yang kompleks dan membingungkan. Namun, secara teknis, maze dibedakan dari labirin. Labirin memiliki sebuah rute yang berliku tetapi tidak memiliki cabang dan tidak dirancang untuk navigasi yang rumit. Sedangkan Maze memiliki jalur yang bercabang dengan tingkat kerumitan yang lebih tinggi. Dalam prakteknya, maze dapat dibangun dengan dinding dan ruangan, pagar, rumput, batang jagung, jerami, buku, batu warna-warni, batu-bata, rumput atau bidang tanaman seperti gandum atau jagung. Jalur dan dinding yang ada pada maze atau labirin telah ditentukan sebelumnya. 


\section{Manfaat Bermain Bagi Anak}

Menurut Montolalu, dkk bahwa

manfaat bermain bagi anak diantaranya:

a. Bermain memicu kreativitas.

Dalam lingkungan bermain yang aman dan menyenangkan, bermain memacu anak menemukan ide-ide serta menggunakan daya khayalnya.

b. Bermain bermanfaat

Mencerdaskan otak.

Bermain merupakan sebuah

media yangsangat penting bagi

proses berpikir anak.

c. Bermain bermanfaat

menanggulangi konflik.

Tingkah laku yang sering muncul adalah tingkah laku menolak, bersaing, agresif, bertengkar, kerja sama, egois, simpatik, marah, ngambek, dan berkeinginan untuk diterima oleh lingkungan sosial.

d. Bermain bermanfaat untuk melatih Empati.

Empati adalah pengenalsan perasaan pikiran, dan sikap orang lain, dapat juga dikatakan pengenalan jiwa orang lain.

e. Bermain bermanfaat mengasah Pancaindra.
Kelima indra, yaitu penglihatan, pendengaran, penciuman, pengucapan dan perabaan merupakan alat-alat yang vital yang perlu diasah sejak anak masih bayi.

f. Bermain sebagai media Terapi (Pengobatan).

Anak menggunakan bermain sebagai salah satu cara untuk mengatasi masalah konflik dan kecemasannya.

g. Bermain itu melakukan penemuan Bermain dapat menghasilkan ciptaan baru. ${ }^{8}$

\section{Metode Penelitian}

\section{Tempat dan waktu Penelitian} Penelitian tindakan kelas ini dilakukan di RA Sabariyah Kelurahan Harjosari II Kecamatan Medan Amplas. Waktu penelitian akan dilaksanakan pada semester dua tahunpelajaran 2016/2017, yaitu bulan Januari sampai bulan Maret 2017.

\section{Siklus Penelitian}

Sebelum melaksanakan penelitian tindakan kelas, peneliti melakukan pra

\footnotetext{
${ }^{8}$ B.E.F, Montolalu, dkk, Bermain dan
} Permainan Anak, (Jakarta: UT, 2007), h.1.191.23 
penelitian. Kemudian melakukan PTK dengan satu siklus untuk melihat peningkatan kemampuan emosional melalui kegiatan bermain maze. Namun apabila pada siklus satu visual spasial anak belum berkembang seperti yang diharapkan, maka peneliti menambah satu siklus sampai visual spasial anak dengan pemanfaatan dengan bermain. desain siklus 1, 2 dan 3

\section{Subjek Penelitian}

Penelitian tindakan kelas ini dilakukan di RA Sabariyah Kelurahan Harjosari II Kecamatan Medan Amplas. Subyek penelitian tindakan kelas ini adalah anak didik kelas kelompok B dengan jumlah siswa 17 anak yang terdiri dari 10 anak laki-laki dan 7 anak perempuan.

\section{Sumber Data}

\section{a. Anak}

Jumlah seluruh anak yang belajar di RA Sabariyah Kelurahan Harjosari II Kecamatan Medan Amplas adalah 17 orang dengan jumlah 10 orang anak laki-laki dan 7 anak perempuan.

\section{b. Guru}

Jumlah guru yang mengajar di RA Sabariyah Kelurahan Harjosari Kecamatan Medan Amplas sebanyak 2 guru.

\section{c. Teman Sejawat dan} Kolabolator

Teman sejawat yang dijadikan penilai pada pelaksanaan PTK adalah Enny Suryani, S.Pdi. dan kolabolator adalah Fitriana

\section{Teknik Pengumpulan Data}

Dalam penelitian ini teknik pengumpulan data diperoleh melalui observasi, dokumen dan wawancara.

a. Observasi

Menurut Riduwan bahwa "Observasi merupakan teknik pengumpulan data, dimana peneliti melakukan pengamatan secara langsung ke objek penelitian untuk melihat dari dekat kegiatan yang dilakukan."23 Observasi dipergunakan untuk mengumpulkan data yang berkaitan dengan aktivitas dalam kegiatan pembelajaran dan peneliti melakukan penilaian terhadap visual spasial anak dengan bermain.

b. Dokumentasi

Dokumentasi adalah mengumpulkan data dengan cara mengalir atau mengambil data-data dari 
catatan, dokumentasi, administrasi yang sesuai dengan masalah yang diteliti. Dalam hal ini dokumentasi diperoleh melalui dokumen-dokumen atau arsip-arsip dari lembaga yang di teliti. ${ }^{24}$ Dokumentasi dilakukan untuk mengetahui visual spasial anak dengan bermain.

\section{Alat Pengumpulan Data PTK}

Alat pengumpulan data yang berupa observasi dilakukan pada saat siklus berlangsung dan tiap siklus direncanakan lima kali pertemuan.

\section{Indikator Kinerja}

Dalam PTK ini yang akan dilihat indikator kinerja penelitian adalah anak dan guru. Guru merupakan fasilitator yang sangat berpengaruh terhadap aktivitas dan peningkatan visual spasial anak.

\section{Teknik Analisis Data}

Dalam penelitian ini tindakan kelas ini digunakan analisis deskripif. Penggunaan analisis deskriptif adalah sebagai berikut:

a. Hasil belajar dianalisis dengan analisis deskriptif komparatif yaitu membandingkan nilai antara siklus I, II dan siklus III dengan indikator kerja paling sedikit $\quad 80 \%$ untuk meningkatkan visual spasial anakmelalui dengan bermain.

b. Observasi maupun wawancara dengan analisis deskriptif kualitatif berdasarkan hasil observasi.

c. Tabulasi data

Tabulasi data adalah membuat table-tabel yang berisikan data yang telah diberi kode sesuai dengan analisis yang dibutuhkan.

d. Menghitung rata-rata Mean merupakan teknik penjelasan kelompok yang didasarkan atas nilai rata-rata dari nilai yang dimaksud.

e. Menyajikan data

Penyajian data dapat dilakukaan dengan mengklasifikasihan data yang diperoleh ke dalam tabel frekuensi dengan rumus:

$P=\frac{F}{N} X 100 \%$

Keterangan:

$\mathrm{P}=$ Anak Mengalami Perubahan

$\mathrm{F}=$ Jumlah anak yang mengalami perubahan

$\mathrm{N}=$ Jumlah seluruh anak ${ }^{25}$

\section{Prosedur Penelitian}

Penelitian ini dilakukan dengan menggunakan desain penelitian tindakan kelas (PTK). Penelitian tindakan kelas dalam bentuk siklus 
yang berulang terdapat empat langkah dalam PTK yang merupakan satu siklus yaitu tahap perencanaan, tahap pelaksanaan, tahap analisis dan tahap refleksi.

\section{Hasil dan Pembahasan Penelitian}

\section{Deskripsi Kondisi Awal}

Tahap prasiklus adalah tahap dimana belum diterapkannya model pembelajaran dengan menggunakan maze. Pelaksanaan pembelajaran pada pra siklus untuk kelas B RA Sabariyah Kelurahan Harjosari II Kecamatan Medan Amplas pada prasiklus ini. Tahap ini bertujuan untuk mengetahui seberapa jauh keaktifan dan kemampuan anak dalam mengikuti pembelajaran di kelas sebelum diterapkannya bermain maze. Pada prasiklus ini, didapatkan informasi mengenai keaktifan dan kemampuan visual spasial anak RA Sabariyah Kelurahan Harjosari Kecamatan Medan Amplas masih jauh dari harapan

Visual spasial anak dengan indikator kemampuan anak dalam menggambar yaitu yang belum berkembang (BB) sebanyak 8 orang anak (47,11\%), yang mulai berkembang (MB) sebanyak 5 orang anak $(29,42 \%)$, berkembang sesuai

harapan (BSH) sebanyak 2 orang anak $(11,76 \%) \quad$ dan yang berkembang sangat baik (BSB) sebanyak 2 orang anak $(11,76 \%)$. Visual spasial anak dengan indikator kemampuan anak menyesuaikan warna yaitu yang belum berkembang (BB) sebanyak 7 orang anak (41,17\%), yang mulai berkembang (MB) sebanyak 5 orang anak $(29,42 \%)$, berkembang sesuai harapan (BSH) sebanyak 3 orang anak $(17,65 \%) \quad$ dan yang berkembang sangat baik (BSB) sebanyak 2 orang anak (11,76\%). Visual spasial anak dengan indikator kemampuan meletakkan bendabenda yaitu yang belum berkembang (BB) sebanyak 7 orang anak (41,17\%), yang mulai berkembang (MB) sebanyak 5 orang anak $(29,42 \%)$, berkembang sesuai harapan (BSH) sebanyak 3 orang anak $(117,65 \%)$ dan yang berkembang sangat baik (BSB) sebanyak 2 orang anak $(11,76 \%)$.

Berdasarkan data yang
diperoleh pada kondisi awal
diketahui bahwa visual spasial anak
melalui kegiatan bermain maze anak
masih rendah, hal ini dapat dilihat
dari hasil yang diperoleh yaitu rata-


rata sebesar $27,44 \%$, maka perlu diadakan perbaikan pembelajaran melalui kegiatan bermain maze di RA Sabariyah Kelurahan Harjosari II Kecamatan Medan Amplas pada siklus 1 .

Pada siklus 1 diketahui bahwa visual spasial anak dengan indicator kemampuan anak dalam menggambar yaitu yang belum berkembang (BB) sebanyak 7 orang anak $(41,17 \%)$, yang mulai berkembang (MB) sebanyak 4 orang anak $(23,53 \%)$, berkembang sesuai harapan (BSH) sebanyak 3 orang anak $(17,65 \%)$ dan yang berkembang sangat baik (BSB) sebanyak 3 orang anak $(17,65 \%)$. Visual spasial anak dengan indikator kemampuan anak menyesuaikan warna yaitu yang belum berkembang (BB) sebanyak 6 orang anak (35,3\%), yang mulai berkembang (MB) sebanyak 4 orang anak $(23,53 \%)$, berkembang sesuai harapan (BSH) sebanyak 2 orang anak (11,76\%) dan yang berkembang sangat baik (BSB) sebanyak 5 orang anak $(29,41 \%)$. Visual spasial anak dengan indikator, kemampuan meletakkan benda-benda yaitu yang belum berkembang (BB) sebanyak 5 orang anak $(29,41 \%)$, yang mulai berkembang (MB) sebanyak 5 orang anak $(29,41 \%)$, berkembang sesuai harapan (BSH) sebanyak 4 orang anak $(23,53 \%)$ dan yang berkembang sangat baik (BSB) sebanyak 3 orang anak $(17,64 \%)$.

Dari data di atas dapat disimpulkan bahwa visual spasial anak pada siklus 1 belum mencapai indikator keberhasilan yang ditentukan adapun rata-ratanya adalah sebesar $39,21 \%$, maka perlu diadakan perbaikan pembelajaran melalui kegiatan bermain maze di RA Sabariyah Kelurahan Harjosari II Kecamatan Medan Amplas pada siklus ke 2.

Dari hasil siklus ke 2 diperoleh Visual spasial anak dengan indikator kemampuan anak dalam menggambar yaitu yang belum berkembang (BB) sebanyak 3 orang anak $(17,65 \%)$, yang mulai berkembang (MB) sebanyak 4 orang anak $(23,53 \%)$, berkembang sesuai harapan (BSH) sebanyak 5 orang anak $(29,41 \%) \quad$ dan yang berkembang sangat baik (BSB) sebanyak 5 orang anak $(29,41 \%)$.Visual spasial anak 
dengan indikator kemampuan anak menyesuaikan warna yaitu yang belum berkembang (BB) sebanyak 5 orang anak (29,41\%), yang mulai berkembang (MB) sebanyak 3 orang anak $(17,65 \%)$, berkembang sesuai harapan (BSH) sebanyak 5 orang anak $(29,41 \%)$ dan yang berkembang sangat baik (BSB) sebanyak 4 orang anak $(23,53 \%)$.Visual spasial anak dengan indikator kemampuan meletakkan benda-benda yaitu yang belum berkembang (BB) sebanyak 4 orang anak (23,53\%), yang mulai berkembang (MB) sebanyak 4 orang anak $(23,53 \%)$, berkembang sesuai harapan (BSH) sebanyak 5 orang anak $(29,41 \%) \quad$ dan yang berkembang sangat baik (BSB) sebanyak 4 orang anak $(23,53 \%)$.

Dari data di atas dapat disimpulkan bahwa visual spasial anak siklus 2 belum mencapai indikator keberhasilan yang ditentukan adapun rata-ratanya adalah sebesar 54,9\% maka perlu diadakan perbaikan pembelajaran melalui kegiatan bermain maze di RA Sabariyah Kelurahan Harjosari II Kecamatan Medan Amplas pada siklus 3.
Dari hasil siklus 3 diperoleh bahwa visual spasial anak dengan indikator kemampuan anak dalam menggambar yaitu yang belum berkembang (BB) sudah tidak ditemukan lagi, yang mulai berkembang (MB) sebanyak 1 orang anak (5,88\%), berkembang sesuai harapan (BSH) sebanyak 8 orang anak $(47,06 \%)$ dan yang berkembang sangat baik (BSB) sebanyak 8 orang anak $(47,06 \%)$.Visual spasial anak dengan indikator kemampuan anak menyesuaikan warna yaitu yang belum berkembang (BB) sebanyak 1 orang anak (6,88\%), yang mulai berkembang (MB) sebanyak 3 orang anak $(17,65 \%)$, berkembang sesuai harapan (BSH) sebanyak 4 orang anak $(23,53 \%)$ dan yang berkembang sangat baik (BSB) sebanyak 8 orang anak $(52,94 \%)$. Visual spasial anak dengan indikator kemampuan meletakkan benda-benda yaitu yang belum berkembang (BB) sebanyak 1 orang anak $(6,88 \%)$, yang mulai berkembang (MB) sebanyak 3 orang anak $(17,65 \%)$, berkembang sesuai harapan (BSH) sebanyak 4 orang anak $(23,53 \%)$ dan yang berkembang sangat baik (BSB) sebanyak 8 orang anak $(52,94 \%)$. 
Dengan demikian berdasarkan data yang diperoleh pada tindakan siklus 3 tingkat pencapaian visual spasial anak sudah berkembang sesuai harapan dan berkembang sangat baik dengan rata-rata $82,355 \%$, maka penelitian hanya dilakukan pada siklus 3 dan tidak perlu diadakan perbaikan pembelajaran melalui kegiatan bermain maze di RA Sabariyah Kelurahan Harjosari II Kecamatan Medan Amplas.

\section{Pembahasan Hasil Penelitian}

Berdasarkan hasil analisis data diperoleh pada kondisi awal diketahui bahwa visual spasial anak masih rendah yaitu rata-rata sebesar $27,44 \%$, maka perlu diadakan perbaikan pembelajaran melalui kegiatan bermain maze di RA Sabariyah Kelurahan Harjosari II Kecamatan Medan Amplas pada siklus 1 .

Pada siklus 1 tingkat pencapaian berkembang sesuai harapan dan berkembang sangat baik masih rendah yaitu rata-rata $39,21 \%$, maka perlu diadakan perbaikan pembelajaran melalui kegiatan bermain maze di RA Sabariyah Kelurahan Harjosari II Kecamatan Medan Amplas.

Pada tindakan siklus 2 tingkat pencapaian berkembang sesuai harapan, akan tetapi belum mencapai tingkat keberhasilan yaitu rata-rata 54,9\% maka perlu diadakan perbaikan pembelajaran melalui kegiatan bermain maze di RA Sabariyah Kelurahan Harjosari II Kecamatan Medan Amplas pada siklus 3.

Berdasarkan hasil penelitian pada siklus 3 diketahui bahwa peningkatan visual spasial anak melalui kegiatan bermain maze pada anak kelompok B RA Sabariyah Kelurahan Harjosari II Kecamatan Medan Amplas telah berhasil dengan nilai rata-rata 82,35\%. Dengan demikian, pelaksanaan tindakan bermain maze tidak perlu dilanjutkan pada siklus berikutnya lagi.

\section{E. Simpulan Dan Saran}

\section{Simpulan}

Berdasarkan dari hasil penelitian dan pembahasan maka dapat disimpulkan bahwa visual spasial anak dapat ditingkatkan dengan menggunakan media bermain maze pada RA Sabariyah Kelurahan Harjosari II Kecamatan Medan Amplas Tahuan ajaran 2015/2017, hal tersebut dapat dilihat dari hasil penelitian pada setiap siklus; prasiklus visual spasial anak sangat rendah yaitu hasil persentase rata-rata sebesar $26,5 \%$, 
pada siklus 1 hasil persentase rata-rata sebesar $41 \%$, pada siklus 2 hasil persentase rata-rata sebesar $57,5 \%$ dan pada siklus 3 rata-rata sebesar $85 \%$.

\section{Saran-saran}

Dari hasil penelitian dan pembahasan di atas maka yang diperoleh dari uraian sebelumnya agar proses belajar lebih efektif bagi anak serta memberikan hasil yang optimal maka disampaikan saran sebagai berikut:

1) Dalam penggunaan kegiatan bermain maze ini disarankan kepada guru lebih sering untuk mengembangkan kegiatan pembelajaran melalui kegiatan bermain maze, agar dalam proses kegiatan pembelajaran kognitif anak dapat meningkat dengan baik.

2) Dengan meningkatnya visual spasial anak pada khususnya guru kelas hendaknya sering memberikan kesempatan pada anak untuk mengenalkan pembelajaran yang menggunakan bermain maze, dalam penerapan sebelumnya guru menjelaskan aturan kegiatan yang lebih jelas agar anak dan kondisi kelas tetap

$$
\begin{aligned}
& \text { terkendali serta guru dapat } \\
& \text { meningkatkan pula } \\
& \text { penggunaan kata atau } \\
& \text { kalimatnya, sehingga anak } \\
& \text { benar-benar memahami } \\
& \text { pentingnya kegiatan bermain } \\
& \text { mazeuntuk kegiatan } \\
& \text { pembelajaran visual spasial } \\
& \text { anak. } \\
& \text { 3) Mengingat kegiatan } \\
& \text { pembelajaran dari penelitian } \\
& \text { ini kegiatan pembelajaran } \\
& \text { visual spasial anak yang } \\
& \text { melalui bermain maze, peneliti } \\
& \text { mengharapkan kepada guru } \\
& \text { dapat meningkatkan visual } \\
& \text { spasial anak melalui kegiatan } \\
& \text { bermain maze, sehingga anak } \\
& \text { dapat menemukan } \\
& \text { pengetahuan yang baru. }
\end{aligned}
$$

\section{Daftar Pustaka}

Dikdasmen. 2010. Pedoman Pengembangan Program Pembelajaran di Taman Kanak-kanak, Jakarta: Kemendiknas.

Depdiknas. 2007. Kurikulum 2003 Standar Komputer $T K$ dan $R A$ Jakarta:Direktorat Jendral Pendidikan Dasar dan Menengah Gardner, Howard. 2008. Kecerdasan Majemuk dan Teori dan Praktik, Jakarta: Indonesia 
Musfiroh, Tadkiroatun. 2008. Cerdas Melalui Bermain, Jakarta: Grasindo

Poerwadarmita, W.J.S. 2007. Kamus Lengkap Bahasa Indonesia Jakarta: Indeks
Slameto.2010.Belajar dan factor-faktor yang mempengaruhinya Jakarta: Rineka Cipta

Susanto, Ahmad. 2011. Perkembangan Anak Usia Dini Pengantar dalam erbagai Aspeknya, Jakarta: Kencana 